\title{
EFFECT OF SOME HERBS AS FEED ADDITIVES ON PERFORMANCE, DIGESTIBILITY, CARCASS CHARACTERISTICS AND BLOOD PARAMETERS OF BROILERS
}

\author{
Sh. A. M. Ibrahim ${ }^{1}$, Magda M. Abdel Fattah ${ }^{2}$, G.M. El Mallah ${ }^{1}$ and Hewida M.H. \\ Elallawy ${ }^{1}$ \\ ${ }^{1}$ Animal production Dept., National Research Center, Center, 33 Bohoos St, (12622), Dokki, Giza, \\ Egypt. \\ ${ }^{2}$ Poultry Nutrition Dept., Animal Prod. Res Inst, Agric. Res. (11268), Dokki, Cairo, Egypt.
}

(Received 11/2 /2019, accepted 19/3 /2019)

SUMMARY

$\mathrm{T}$ wo hundreds and sixteen one-day-old Coob-500 chicks were fed various diets for 6-weeks period and were equally divided into 6 treatment groups of 36 birds each, ( 3 replicates per group, of 12 birds each), using a completely randomized design, for 42 days. The diets included a control diet (without any additives) while the other five diets contained sweet basil (Ocimum basilicum L), fennel (Foeniculum vulgare), cinnamon (Cinnamomum Zeylanicum), oregano (Origanum vulgare L.) and there blend at $1 \%$ level as feed additives $(10 \mathrm{~g} / \mathrm{kg}$ feed $)$. The results revealed that herb mixture treatment birds significantly increased the live body weight by $9 \%$ followed by the oregano treatment by $4.9 \%$ then the fennel treatment by $2.8 \%$ compared to the control group. However, the dietary herbs significantly improved the feed conversion ratio for Basil and Fennel treatments by the same value 5.6\%, Cinnamon by 6.2, Oregano by 7.7 and for mixture treatments by $9.2 \%$ compared to the control group. Basil significantly decreased the abdominal fat by $53 \%$ and the liver weight by $7 \%$ compared to the control group. The mixture and oregano treatments significantly decreased the gizzard weight by $35.3 \%$ and $34.2 \%$ respectively, compared to the control group. Basil significantly decreased the total blood serum cholesterol by $17.2 \%$ compared to the control group. The fennel and oregano significantly increased the A/G ratio at the same value by $29 \%$ compared to the control group. Cinnamon significantly improved the CP digestibility by $3.15 \%$ compared to the control group. It can be concluded that the mixture of basil, fennel, cinnamon and oregano at the level of $1 \%$ significantly increased most growth performance parameters followed by oregano, cinnamon, basil and fennel.

Keywords: Herbs, broiler, growth performance, carcass quality, digestibility and blood parameters.

\section{INTRODUCTION}

Because of increasing antibiotic resistance, medicinal plants considers the most popular natural alternatives and are currently gaining more importance for poultry and animal production. Such novel therapeutic strategy involves the use of natural antioxidant, antibacterial, anti-diarrheal, antimicrobial and anti-inflammatory activities, anticarcinogenic, antiaging, antihistaminic, antiarthritic, antifungal, and antiviral compounds (Khanna, 2005).

Sweet basil, Ocimum basilicum L (Lamiaceae) commonly known as "Holy basil", is one of the most important wildly used spices and has been shown to have antioxidant (Dasgupta et al., 2004), antibacterial, and anti-diarrheal activities (Lu Y et al., 2014) as well as anti-inflammatory activities in acute and chronic inflammation (Rodrigues et al., 2017). The dominant or major phytochemical constituents of dry leaf are geraniol (Saha et al., 2012), linalool, methyl-chavikol (Estragol), methyl cinnamate, linolen, rosmarinic acid, citral, eugenol, and geraniol (Lalko and Api 2006), thyrsiflora (Avetisyan et al., 2017) and camphor (Schulz et al., 2003), which have specific functions and using various secondary metabolic pathways (Avetisyan et al., 2017).

Cinnamon, Cinnamomum Zeylanicum (Lauraceae) have principle components cinnamaldehyde possessed metal ion chelating lipo-protective, antibacterial and anti-proliferative activities (Erdogru et al., 2003), antiinflammatory (Han and Parker 2017) and have eugenol acting as antioxidant (Pandey et al., 
2012) which acting with cinnamic acid and cineol component to neutralize free radicals to hence they mitigate their harmful effects indicating their usefulness in food and pharmaceutical sector (Sharma et al., 2016) as well as provides protection against allergens causing atherosclerosis (Nayak et al., 2017).

Oregano, Origanum vulgare L (Lamiaceae), Origanum perennial herbaceous aromatic plant grows in worldwide (Lagouri et al., 1993). About 50\% of oregano oil consists of phenolic compounds (primarily carvacrol and thymol) and also contains P-cymene, caryophyllene, and 3-carene (Han et al., 2017), sesquiterpene, terpinene, terpineol alcohol, flavonoids, and other compounds (Arcila-Lozano et al., 2004) which provides evidence for antioxidant proprieties (Botsoglou et al., 2004).

Fennel, Foeniculum vulgare L (Umbelliferae), as an aromatic nature and flavour in culinary and traditional applications is widely cultivated in the tropical and temperate regions of the world (Goswami and Chatterjee 2014) has antioxidant proprieties (de Marino.,2007), hepatoprotective (Ozbek et al.,2003), antimicrobial (Kaur and Arora 2009), oestrogenic (Albert 1980), acaricidal (Kim et al., 2002), antihirsutism (Javidnia et al., 2003), antidiabetic and anti-inflammatory (Choi and Hwang 2004) and antithrombotic (Tognolini et al., 2007).

Our theoretical hypnosis that both sweet basil (Akbarian et al., 2016) and fennel (Botsoglou et al., 2005) share the secretion of ghrelin that can suppress appetite and glucagon-like peptide while both cinnamon (Tabak et al., 1999) and oregano (Giannenas et al., 2016) inhibit the free urease in chicks that inhibit the undesirable intestinal microflora leading to improve digestion and accordingly growth performance. Therefore this study aimed to evaluate the effect of sweet basil, fennel, cinnamon, oregano and there blend at the $1 \%$ levels as feed additives on broilers performance, carcass characteristics, blood parameters and digestibility.

\section{MATERIALS AND METHODS}

This experiment was carried in Nubaria research and production station, National Research Centre and was conducted to study the effect of sweet basil, fennel, cinnamon, oregano and there blend at the $1 \%$ level as feed additives in Coob-500 chick's diets on broilers performance, carcass characteristics, blood parameters and digestibility. A total of 216 unsexed one- week-old broiler chicks were randomly and equally divided into 6 treatment groups of 36 birds each, (3 replicates per group, of 12 birds each).

All chicks were brooded floor pens and kept in temperature controlled and similar management conditions. The light regimen at 1 day age was 24day/ light which this being maintained until the end of the study. Feed and water were offered ad-libitum access to both feed and water throughout the study period of $42 \mathrm{~d}$. The diet was formulated to cover the nutrient requirements according to NRC (1994). All the medicinal plants used were sun dried and grinded. All chicks were fed commercial diet during the first week of age before receiving the experimental diets. The feeding program contained a starter and finisher diets that were fed from 1-day to 3 weeks with $3100 \mathrm{Kcal} \mathrm{ME} / \mathrm{Kg}$ and $23 \% \mathrm{CP}$ and from 4 to 6 weeks with $3200 \mathrm{Kcal} \mathrm{ME} / \mathrm{Kg}$ and $20 \% \mathrm{CP}$ as basal diet respectively (Table 1). The medicinal plants used in this study were dried grinded leaves of sweet basil, fennel and oregano, while the cinnamon was the dried park. A basal diet with no additives was used as control diet (T1) while, the other 5 groups (T2;T6) were generated by adding sweet basil, fennel, cinnamon, oregano and there blend, respectively, at $1 \%$ of feed to the basal diet.

Blood samples were collected in tubes from the brachial vein) 5 chick/ group), and centrifuged at $3000 \mathrm{rpm}$ for 15 minutes to separate clear serum which stored at $20^{\circ} \mathrm{C}$ for determination of some blood serum constituents as total protein (TP), albumin (AL), globulin (GL), total lipids (TL), cholesterol $(\mathrm{CHO})$, aspartate transaminases (AST) and alanine transaminase (ALT) by spectrophotometer using available commercial kits. At the end of the experimental period, all birds in feeding trials were used in digestibility trials over period of 7 days to determine the nutrient digestibility coefficients and nutritive values of the tested diets. Feed intake of experimental rations and weight of feces were daily recorded

Data were analyzed using general linear model (GLM) procedure of statistical system (SPSS, 1997). Duncan's multiple range test (Duncan, 1955) was used to separate means when the dietary treatment effect was significant. At the end of the experiment 9 birds per treatment (three birds per pen) were randomly selected to process carcass quality. 
Table (1): Composition and calculated analysis of the experimental diets.

\begin{tabular}{|c|c|c|}
\hline Ingredient $\%$ & Starter & Finisher \\
\hline Yellow corn & 48.48 & 55.38 \\
\hline Soybean meal (44\%) & 40.00 & 30.60 \\
\hline Corn gluten meal $(62 \%)$ & 2.00 & 3.90 \\
\hline Vegetable oil & 5.90 & 6.60 \\
\hline Di-calcium phosphate & 1.70 & 1.80 \\
\hline Limestone & 1.20 & 1.00 \\
\hline Sodium chloride & 0.30 & 0.30 \\
\hline Vit. Min. Pre mix ${ }^{*}$ & 0.30 & 0.30 \\
\hline Dl-methionine & 0.12 & 0.12 \\
\hline Total & 100 & 100 \\
\hline \multicolumn{3}{|l|}{ Calculated analysis** } \\
\hline Crude protein $\%$ & 23.01 & 20.06 \\
\hline $\mathrm{ME} \mathrm{Kcal/kg}$ & 3102 & 3230 \\
\hline Lysine $\%$ & 1.24 & 1.10 \\
\hline Methionine $\%$ & 0.45 & 0.45 \\
\hline Cystine\% & 0.37 & 0.34 \\
\hline Calcium $\%$ & 0.96 & 0.89 \\
\hline Available-p $\%$ & 0.46 & 0.45 \\
\hline \multicolumn{3}{|c|}{$\begin{array}{l}\text { *Vitamins and minerals premix were free from folic acid: each } \mathrm{kg} \text { contains vit A } 12000 \mathrm{Iu} \text {, vit.D3 } 3000 \mathrm{Iu} \text {, vit. E } 12 \\
\mathrm{mg} \text {, vit. } \mathrm{K} \mathrm{lmg} \text {, vit B12 } 0.02 \mathrm{mg} \text {, vit B1 } \mathrm{lmg} \text {, vit B2 } 4 \mathrm{mg} \text {, vit B6 } 5 \mathrm{mg} \text {, Nicotinic acid } 20 \mathrm{mg} \text {, Biotin } 0.05 \mathrm{mg} \text {, Choline } \\
\text { chloride } 0.16 \mathrm{mg} \text {, cupper } 3 \mathrm{mg} \text {, iron } 30 \mathrm{mg} \text {, manganese } 40 \mathrm{mg}, . z \mathrm{inc} 45 \mathrm{mg} \text { and selenium } 3 \mathrm{mg} ., .\end{array}$} \\
\hline
\end{tabular}

\section{RESULTS AND DISCUSSIONS}

\section{Digestibility:}

Dietary cinnamon significantly improved the CP digestibility in broiler by $3.15 \%$ compared to the control group (Table 2). This result may be due to the cinnamaldehyde beneficial effect on the enzymes secretions and gut health as in weaning pigs (Cho et al., 2006 and Yan et al., 2012). Dietary basil, fennel, oregano or it's there mixture treatments slightly improved the CP digestibility in broiler compared to the control group (Table 2). These digestibility improvements in broiler chickens may stem from phytogenic properties to enhance digestion via the enhancement of digestive secretions (Brenes and Roura, 2010 and Lee et al., 2004). Moreover, all herbs treatments and their mixture improved (P>0.05) OM, CP, EE, CF and NFE digestibility compared to control.

Table (2): Digestibility of broiler as affected by herbs plants.

\begin{tabular}{lccccccc}
\hline Item & $\begin{array}{c}\text { Control } \\
(\mathrm{T} 1)\end{array}$ & $\begin{array}{c}\text { Basil } \\
(\mathrm{T} 2)\end{array}$ & $\begin{array}{c}\text { Fennel } \\
(\mathrm{T} 3)\end{array}$ & $\begin{array}{c}\text { Cinnamon } \\
(\mathrm{T} 4)\end{array}$ & $\begin{array}{c}\text { Oregano } \\
(\mathrm{T} 5)\end{array}$ & $\begin{array}{c}\text { Mix } \\
(\mathrm{T} 6)\end{array}$ & $\begin{array}{c}\text { Overall } \\
\text { mean } \pm \text { SE }\end{array}$ \\
\hline OM\% & 68.44 & 71.42 & 72.36 & 72.96 & 69.75 & 72.63 & $71.26 \pm 0.92$ \\
CP\% & $77.38^{\mathrm{b}}$ & $82.12 \mathrm{ab}$ & $82.96^{\mathrm{ab}}$ & $85.53^{\mathrm{a}}$ & $79.82^{\mathrm{ab}}$ & $83.78^{\mathrm{ab}}$ & $81.93 \pm 0.01$ \\
EE \% & 65.64 & 73.52 & 72.25 & 67.46 & 73.97 & 71.02 & $70.64 \pm 1.73$ \\
CF\% & 33.70 & 32.11 & 43.01 & 36.53 & 30.07 & 42.22 & $36.27 \pm 2.15$ \\
NFE\% & 67.56 & 69.18 & 69.86 & 71.14 & 67.41 & 70.26 & $69.24 \pm 0.91$ \\
\hline
\end{tabular}

$a, b, c, d$ : In each column means having different superscripts are significantly different $(p<0.05)$.

\section{Broilers performance:}

Dietary herb mixture treatment birds (T6) significantly increased the live body weight by $9 \%$ followed by the oregano treatment (T5) by $4.9 \%$ and the fennel treatment (T3) by $2.8 \%$ compared to the control group (Table 3). The result of the mixture treatment (T6) may be due to the stimulation of the growth and the improving at the intestinal microbial balance (including reduction of coliform bacteria and an increase in Lactobacillus spp. Counts) as reported by Cetin et al. (2016). The result of oregano treatment (T5) may be due to its beneficial effect on prevention of coccidiosis in broilers as reported by Mohiti and 
Ghanaatparast (2015) and by Giannenas et al. (2016) in broilers and by Forte et al. (2017) in pigs. The result in fennel treatment (T3) may be due to the appetite stimulation beneficial effects of its essential oils including the improvement of endogenous digestive enzyme secretion and immune response activation (Botsoglou et al., 2005). Results at Table (3) showed significant improve of feed conversion ratio in basil, fennel, cinnamon, oregano and mixture treatments by 5.6, 5.6, 6.2, 7.7 and $9.2 \%$ respectively, compared to the control group. These results may be due to the ability of these herbs on the reactive and bring about oxidation effect of bio-molecules of proteins, lipids and nucleic acids which are associated with many degenerative diseases (Sharma et al., 2016). There were gradually satisfactory while insignificant decreasing in feed intake by $(4.2,3.6,3.1,3.0$ and $0.8 \%$ ) for cinnamon, basil, fennel, oregano and mixture treatments, respectively, compared to the control group (Table 3). The result in cinnamon treatment (T4) may be due to the intestinal antimicrobial effect of clindamycin that inhibit the free urease in chicks (that catalyzes the hydrolysis of urea into carbon dioxide and ammonia) than on whole cell urease (Tabak et al., 1999 and Shahverdi et al., 2007). The result in basil treatment (T2) may be due to the high fiber and mucilage 10\%-15\% (Akbarian et al., 2016) or to its secretion of ghrelin that can suppress appetite and glucagon-like peptide that can enhance postprandial satiety time (Karhunen et al., 2010) which occupying stomach and decreasing food glysemic index (Koocheki et al., 2007). The result in fennel treatment (T3) may be due to its effect in decreasing hunger, less prospective food consumption, and increased feelings of fullness as shown in women (Bae et al., 2015). The result in oregano treatment (T5) may be due to the lower palatability that decreased feed intake through a positive-feedback reward mechanism (Yeomans et al., 1996).

Significant improvement in feed conversion values were recorded for the mixture treatment by $9 \%$, the oregano treatment by $4.9 \%$ and the fennel treatment by $2.8 \%$, compared to the control group (Table 3 ). These results may be due to the repetitive exposure to spice odor that gradually increase the odor pleasantness within the framework set by the chemical characteristics of the aroma compounds as well as the familiar odors that mostly rated as pleasant (Knaapila et al., 2017).

Table (3): Broiler performance as affected by herbs plants.

\begin{tabular}{|c|c|c|c|c|c|c|c|}
\hline Item & $\begin{array}{c}\text { Control } \\
\text { (T1) }\end{array}$ & $\begin{array}{l}\text { Basil } \\
(\mathrm{T} 2)\end{array}$ & $\begin{array}{c}\text { Fennel } \\
\text { (T3) }\end{array}$ & $\begin{array}{c}\text { Cinnamon } \\
\text { (T4) }\end{array}$ & $\begin{array}{c}\text { Oregano } \\
(\mathrm{T} 5)\end{array}$ & $\begin{array}{l}\text { Mix } \\
(\mathrm{T} 6) \\
\end{array}$ & $\begin{array}{c}\text { Overall mean } \\
\pm \mathrm{SE}\end{array}$ \\
\hline \multicolumn{8}{|c|}{ Body weight: } \\
\hline At 1 week & 94.97 & 94.53 & 94.64 & 94.75 & 94.53 & 94.86 & $94.71 \pm 0.15$ \\
\hline At 3 Week & $840.73^{\mathrm{c}}$ & $865.98^{\mathrm{bc}}$ & $873.85^{\mathrm{bc}}$ & $870.90^{\mathrm{bc}}$ & $900.94^{\mathrm{b}}$ & $959.87^{\mathrm{a}}$ & $885.38 \pm 10.18$ \\
\hline At 6 Week & $1730.4^{\mathrm{d}}$ & $1768.5^{\mathrm{cd}}$ & $1779.3^{\mathrm{bc}}$ & $1764.9^{\mathrm{cd}}$ & $1816.0^{\mathrm{b}}$ & $1886.1^{\mathrm{a}}$ & $1790.9 \pm 12.88$ \\
\hline \multicolumn{8}{|c|}{ Body weight gain: } \\
\hline 1-3 Week & $745.75^{\mathrm{c}}$ & $771.46^{\mathrm{bc}}$ & $779.21^{\mathrm{bc}}$ & $776.15^{\mathrm{bc}}$ & $806.41^{\mathrm{b}}$ & $865.01^{\mathrm{a}}$ & $790.66 \pm 10.18$ \\
\hline 4-6 Week & $889.69^{\mathrm{b}}$ & $902.49^{b c}$ & $905.46^{\mathrm{bc}}$ & $893.96^{\mathrm{b}}$ & $915.03^{b c}$ & $926.24^{\mathrm{a}}$ & $905.48 \pm 4.20$ \\
\hline 1-6 Week & $1635.4^{\mathrm{d}}$ & $1674.0^{\mathrm{cd}}$ & $1684.7^{\mathrm{bc}}$ & $1670.1^{\mathrm{cd}}$ & $1721.4^{\mathrm{b}}$ & $1791.3^{\mathrm{a}}$ & $1696.1 \pm 12.89$ \\
\hline \multicolumn{8}{|l|}{ Feed intake: } \\
\hline 1-3 Week & $1266.6^{\mathrm{b}}$ & $1243.8^{\mathrm{b}}$ & $1267.1^{\mathrm{b}}$ & $1267.6^{\mathrm{b}}$ & $1288.7^{\mathrm{b}}$ & $1441.1^{\mathrm{a}}$ & $1295.8 \pm 19.69$ \\
\hline 4-6 Week & $1925.2^{\mathrm{a}}$ & $1832.8^{\mathrm{ab}}$ & $1825.7^{\mathrm{ab}}$ & $1790.0^{\mathrm{ab}}$ & $1808.8^{\mathrm{ab}}$ & $1725.9^{b}$ & $1818.1 \pm 23.42$ \\
\hline 1-6 Week & 3191.8 & 3076.7 & 3092.8 & 3057.6 & 3097.5 & 3166.9 & $3113.9 \pm 24.16$ \\
\hline \multicolumn{8}{|c|}{ Feed conversion: } \\
\hline 1-3 Week & $1.70^{\mathrm{a}}$ & $1.61^{\mathrm{ab}}$ & $1.63^{\mathrm{bc}}$ & $1.63^{\mathrm{bc}}$ & $1.60^{\mathrm{c}}$ & $1.67^{\mathrm{ab}}$ & $1.64 \pm 0.01$ \\
\hline 4-6 Week & $2.16^{\mathrm{a}}$ & $2.03^{\mathrm{ab}}$ & $2.01^{\mathrm{ab}}$ & $2.00^{\mathrm{ab}}$ & $1.98^{\mathrm{b}}$ & $1.86^{\mathrm{b}}$ & $2.01 \pm 0.028$ \\
\hline 1-6 Week & $1.95^{\mathrm{a}}$ & $1.84^{\mathrm{b}}$ & $1.84^{\mathrm{b}}$ & $1.83^{\mathrm{b}}$ & $1.80^{\mathrm{b}}$ & $1.77^{\mathrm{b}}$ & $1.84 \pm 0.02$ \\
\hline
\end{tabular}

\section{Carcass characteristics:}

The sweet basil treatment (T2) significantly decreased the abdominal fat by $53 \%$ compared to the control group (Table 4). This result may be due to its ability to suppress endogenous glucose release, inhibit glycogenolysis and/or stimulate glycogenesis (Ezeani et al., 2017) or may be due to that basil inhibited $\alpha$-amylase and intestinal sucrase and maltase (El-Beshbishy and Bahashwan 2012). However, the basil treatment significantly increased the liver weight by $7 \%$ compared to the control group (Table 4). This result is agreement with the previous of decreasing the abdominal fat which may be due to the enhanced effect of basil of glucose mobilization by stimulating hepatic glycogen synthesis by the increase in liver glycogen content that explane its capablability of decreasing glucose entering portal vein from the gut or glucose production from starch (Matsui et al., 2001). The mixture (T6) and oregano (T5) 
treatments significantly decreased the gizzard weight by $35.3 \%$ and $34.2 \%$ respectively, compared to the control group (Table 4). These results may be attributed to the oregano bioactive compounds, carvacrol and thymol in suppressing the growth of undesirable intestinal microflora, and concomitantly improve nutrient absorption (Visek, 1978) via including a reduction of coliform bacteria and an increase in Lactobacillus spp. Counts) as reported in chickens by Cetin et al. (2016).

Table (4): Carcass characteristics as affected by herbs plants.

\begin{tabular}{llllllll}
\hline Item & $\begin{array}{l}\text { Control } \\
(\mathrm{T} 1)\end{array}$ & $\begin{array}{l}\text { Basil } \\
(\mathrm{T} 2)\end{array}$ & $\begin{array}{l}\text { Fennel } \\
(\mathrm{T} 3)\end{array}$ & $\begin{array}{l}\text { Cinnamon } \\
(\mathrm{T} 4)\end{array}$ & $\begin{array}{l}\text { Oregano } \\
(\mathrm{T} 5)\end{array}$ & $\begin{array}{l}\text { Mix } \\
(\mathrm{T} 6)\end{array}$ & $\begin{array}{l}\text { Overall } \\
\text { mean } \pm \text { SE }\end{array}$ \\
\hline Carcass yield \% & $69.46^{\mathrm{ab}}$ & $68.45^{\mathrm{b}}$ & $70.78^{\mathrm{ab}}$ & $73.63^{\mathrm{a}}$ & $69.48^{\mathrm{ab}}$ & $72.65^{\mathrm{ab}}$ & $70.47 \pm 0.66$ \\
Abdominal fat \% & 0.66 & 0.31 & 0.72 & 0.47 & 0.58 & 0.49 & $0.54 \pm 0.08$ \\
Gizzard \% & $2.95^{\mathrm{a}}$ & $2.84^{\mathrm{a}}$ & $2.82^{\mathrm{a}}$ & $2.53^{\mathrm{ab}}$ & $1.94^{\mathrm{bc}}$ & $1.91^{\mathrm{c}}$ & $2.50 \pm 0.12$ \\
Liver \% & 2.46 & 2.62 & 2.39 & 2.39 & 2.42 & 2.17 & $2.41 \pm 0.07$ \\
Hart \% & $0.60^{\mathrm{ab}}$ & $0.54^{\mathrm{ab}}$ & $0.69^{\mathrm{a}}$ & $0.48^{\mathrm{b}}$ & $0.50^{\mathrm{b}}$ & $0.48^{\mathrm{b}}$ & $0.54 \pm 0.03$ \\
Spleen \% & 0.19 & 0.19 & 0.24 & 0.25 & 0.23 & 0.18 & $0.21 \pm 0.02$ \\
Edible parts \% & $77.00^{\mathrm{ab}}$ & $76.48^{\mathrm{ab}}$ & $78.69^{\mathrm{ab}}$ & $81.04^{\mathrm{a}}$ & $76.09^{\mathrm{b}}$ & $79.21^{\mathrm{ab}}$ & $78.09 \pm 0.63$ \\
\hline
\end{tabular}

$a, b, c, d$ : In each column means having different superscripts are significantly different ( $p<0.05)$.

\section{Blood parameters:}

Dietary basil (T2) significantly decreased the total cholesterol in blood broiler by $17.2 \%$ compared to the control group (Table 5). These results may be attributed to the effect of basil in stimulating insulin secretion that improves the action of lipoprotein lipase enzyme and/or by sensitization of target organs such as adipose tissue to insulin action as reported in mice by Eddouks et al. (2003). The fennel and oregano treatments (T3\&T5) significantly increased the A/G ratio at the same value by $29 \%$ compared to the control group (Table 5). These results may be due to the appreciable anti-inflammatory and immunomodulatory that including inhibitory effects on lymphocyte activation, suppression of cellular and humoral immunity and induction of apoptosis (Amirghofran 2010).

Table (5): Blood parameters of broiler as affected by herbs plants.

\begin{tabular}{llllllll}
\hline Item & $\begin{array}{l}\text { Control } \\
(\mathrm{T} 1)\end{array}$ & $\begin{array}{l}\text { Basil } \\
(\mathrm{T} 2)\end{array}$ & $\begin{array}{l}\text { Fennel } \\
(\mathrm{T} 3)\end{array}$ & $\begin{array}{l}\text { Cinnamon } \\
(\mathrm{T} 4)\end{array}$ & $\begin{array}{l}\text { Oregano } \\
(\mathrm{T} 5)\end{array}$ & $\begin{array}{l}\text { Mix } \\
(\mathrm{T} 6)\end{array}$ & $\begin{array}{l}\text { Overall mean } \\
\pm S E\end{array}$ \\
\hline Total Protein\% & 4.17 & 3.95 & 3.88 & 3.80 & 3.80 & 4.28 & $3.97 \pm 0.14$ \\
Albumin \% & 0.99 & 0.95 & 1.10 & 0.96 & 1.09 & 0.95 & $1.01 \pm 0.04$ \\
Globulin \% & 3.18 & 2.99 & 2.78 & 2.84 & 2.71 & 3.33 & $2.97 \pm 0.12$ \\
A/G ratio \% & $0.31^{\mathrm{b}}$ & $0.32^{\mathrm{ab}}$ & $0.40^{\mathrm{a}}$ & $0.34 \mathrm{a}^{\mathrm{b}}$ & $0.40^{\mathrm{a}}$ & $0.30^{\mathrm{b}}$ & $0.34 \pm 0.01$ \\
T. Lipids \% & 0.27 & 0.35 & 0.30 & 0.31 & 0.34 & 0.33 & $0.31 \pm 0.01$ \\
Cholesterol \% & 158.33 & 141.10 & 157.10 & 135.50 & 158.20 & 138.03 & $148.04 \pm 4.34$ \\
AST \% & 22.60 & 24.13 & 25.90 & 24.57 & 23.43 & 23.83 & $24.08 \pm 0.61$ \\
ALT \% & $11.04^{\mathrm{ab}}$ & $12.78^{\mathrm{ab}}$ & $14.17^{\mathrm{a}}$ & $10.92^{\mathrm{ab}}$ & $9.92^{\mathrm{b}}$ & $11.62^{\mathrm{ab}}$ & $11.74 \pm 0.53$ \\
\hline
\end{tabular}

$a, b, c, d$ : In each column means having different superscripts are significantly different $(p<0.05)$.

\section{CONCLUSION}

It may be concluded that added $1 \%$ of basil, fennel, cinnamon, oregano and mixture to the diet improved broiler performance.

\section{REFERENCES}

Akbarian, S.A., S. Asgary, A. Feizi, B. Iraqi and G. Askari (2016). Comparative study on the effect of Plantago psyllium and Ocimum basilicum seeds on anthropometric measures in nonalcoholic fatty liver patients. Int. J. Prev. Med., 10: 7:114. 
Albert-Puleo, M. (1980). Fennel and anise as estrogenic agents. J. Ethnopharmacol.; 2(4): 337-344.

Amirghofran, Z. (2010). Medicinal plants as immunosuppressive agents in traditional Iranian medicine. Iran J. Immunol., 7(2):65-73.

Arcila-Lozano, C.C., G. Loarca-Piña, S. Lecona-Uribe, E. González de Mejía (2004). Oregano: properties, composition and biological activity. Arch Latinoam Nutr.; 54(1):100-11.

Avetisyan, A., A. Markosian, M. Petrosyan, N. Sahakyan, A. Babayan, S. Aloyan and A. Trchounian (2017). Chemical composition and some biological activities of the essential oils from basil ocimum different cultivars. BMC Complement Altern Med. Jan 19;17(1):60.

Bae, J., J. Kim, R. Choue and H. Lim (2015). Fennel (Foeniculum vulgare) and fenugreek (Trigonella foenum-graecum) tea drinking suppresses subjective short-term appetite in overweight women. Clin. Nutr. Res., 4(3):168-174.

Botsoglou, N., P. Florou-Paneri, E. Botsoglou, V. Dotas, I. Giannenas, A. Koidis and P. Mitrakos (2005). The effect of feeding rosemary, oregano, saffron and $\alpha$ "-tocopheryl acetate on hen performance and oxidative stability of eggs. South African Journal of Animal Science.35(3):143-151.

Botsoglou, N.A., P. Florou-Paneri, E. Christaki, I. Giannenas and A.B. Spais (2004). Performance of rabbits and oxidative stability of muscle tissues as affected by dietary supplementation with oregano essential oil. Arch. Anim. Nutr., 58(3):209-18.

Brenes, A. and E. Roura (2010). Essential oils in poultry nutrition: main effects and modes of action. Anim Feed Sci Tech.158(1e2):1e14.

Cetin, E., A. Yibar, D. Yesilbag, I. Cetin and S.S. Cengiz (2016). The effect of volatile oil mixtures on the performance and ilio-caecal microflora of broiler chickens. Br. Poult. Sci.; 57(6):780-787.

Choi, E.M. and J.K. Hwang (2004). Antiinflammatory, analgesic and antioxidant activities of the fruit of Foeniculum vulgare. Fitoterapia. Sep;75(6):557-65.

Cho, J.H., Y.J. Chen, B.J. Min, H.J. Kim, O.S. Kwon, K.S. Shon, I.H. Kim, S.J. Kim and A. Asamer (2006). Effects of essential oils supplementation on growth performance, IgG concentration and fecal noxious gas concentration of weaned pigs. Asian-Aust. J. Anim. Sci., 19:80-85.

Dasgupta, T., A.R. Rao and P.K. Yadava (2004). Chemomodulatory efficacy of basil leaf (Ocimum basilicum) on drug metabolizing and antioxidant enzymes, and on carcinogen - induced skin and forestomach papillomagenesis. Phytomedicine,.11(2-3):139-151.

De Marino, S., F. Gala, N. Borbone, F. Zollo, S. Vitalini, F. Visioli and M. Iorizzi (2007). Phenolic glycosides from Foeniculum vulgare fruit and evaluation of antioxidative activity. Phytochemistry.; 68(13):1805-12.

Duncan, D.B. (1955). Multiple Rang and Multiple F-Test Biometrics, 11: 1- 42.

Eddouks, M., H. Jouad, M. Maghrani, A. Lemhadri and R. Burcelin (2003). Inhibition of endogenous glucose production accounts for hypoglycemic effect of Spergulariapurpurea in streptozotocin mice. Phytomedicine.; 10(6-7):594-9.

El-Beshbishy, H. and S. Bahashwan (2012). Hypoglycemic effect of basil (Ocimum basilicum) aqueous extract is mediated through inhibition of $\alpha$-glucosidase and $\alpha$-amylase activities: an in vitro study. Toxicol Ind Health. Feb; 28(1):42-50.

Erdogru, T., M.F. Usta, M. Ates and S. Yigit (2003). Development of Peyronie's disease during long-term colchicine treatment. Int Urol Nephrol. ;35(2):207-8.

Ezeani, C., I. Ezenyi, T. Okoye and C. Okoli (2017). Ocimum basilicum extract exhibits antidiabetic effects via inhibition of hepatic glucose mobilization and carbohydrate metabolizing enzymes. J Intercult Ethnopharmacol., 6(1):22-28.

Forte, C., D. Ranucci, D. Beghelli, R. Branciari, G. Acuti, L. Todini, C. Cavallucci and M. TrabalzaMarinucci (2017). Dietary integration with oregano (Origanum vulgare L.) essential oil improves growth rate and oxidative status in outdoor-reared, but not indoor-reared, pigs. J. Anim. Physiol. Anim. Nutr. (Berl)., 101(5):e352-e361.

Giannenas, I., P. Florou-Paneri, M. Papazahariadou, E. Christaki, N.A. Botsoglou and A.B. Spais (2016). Effect of dietary supplementation with oregano essential oil on performance of broilers after 
experimental infection with Eimeria tenella. BMC Complement Altern. Med.. 16: 156. Published online May 31.

Goswami, N. and S. Chatterjee (2014). Assessment of free radical scavenging potential and oxidative DNA damage preventive activity of Trachyspermum ammi L. (carom) and Foeniculum vulgare Mill. (fennel) seed extracts. Biomed. Res. Int., :582767.

Han, F., G.Q. Ma, M. Yang, L. Yan, W. Xiong, J.C. Shu, Z.D. Zhao and H.L. Xu (2017). Chemical composition and antioxidant activities of essential oils from different parts of the oregano. J. Zhejiang Univ. Sci., B., 18(1):79-84.

Han, X. and T.L. Parker (2017). Antiinflammatory activity of Cinnamon (Cinnamomum zeylanicum) Bark Essential Oil in a Human Skin Disease Model. Phytother Res. Jul; 31(7):1034-1038.

Javidnia, K., L. Dastgheib, S. Mohammadi Samani and A. Nasiri (2003). Antihirsutism activity of Fennel (fruits of Foeniculum vulgare) extract. A double-blind placebo controlled study. Phytomedicine. ; 10(6-7):455-8.

Karhunen, L.J., K.R. Juvonen, S.M. Flander, K.H. Liukkonen, L. Lähteenmäki, M. Siloaho M, Laaksonen DE, Herzig KH, Uusitupa MI, Poutanen KS (2010). A psyllium fiber enriched meal strongly attenuates postprandial gastrointestinal peptide releasein healthy young adults. J Nutr. Apr; 140(4):737-44.

Kaur, G.J. and D.S. Arora (2009). Antibacterial and phytochemical screening of Anethum graveolens, Foeniculum vulgare and Trachyspermum ammi. BMC Complement Altern. Med., 6: 9:30. doi: 10.1186/1472-6882-9-30.

Khanna, S., V. Patel, C. Rink, S. Roy and C.K. Sen (2005). Delivery of orally supplemented alphatocotrienol to vital organs of rats and tocopherol-transport protein deficient mice. Free Radic. Biol. Med., Nov 15;39(10):1310-9.

Kim, D.H., S.I. Kim, K.S. Chang and Y.J. Ahn (2002). Repellent activity of constituents identified in Foeniculum vulgare fruit against Aedes aegypti (Diptera: Culicidae). J. Agric. Food Chem.,; 50(24):6993-6.

Knaapila, A., O. Laaksonen, M. Virtanen, B. Yang, H. Lagstrom and M. Sandell (2017). Pleasantness, familiarity, and identification of spice odors are interrelated and enhanced by consumption of herbs and food neophilia. Appetite.; 109:190-200.

Koocheki, A., S.M.A. Razavi, E. Milani, T. M. Moghadam, M. Abedini, S. Alamatiyan and S. Izadkhah (2007). Physical properties of watermelon seed as a function of moisture content and variety. Mashhad, Iran, 21(4): 349-359.

Lagouri, V., G. Blekas and M. Tsimidou (1993). Composition and antioxidant activity of essential oils from oregano plants grown wild in Greece. Z Lebensm Unters Forsch.; 197(1):20-23.

Lalko, J. and A.M. Api (2006). Investigation of the dermal sensitization potential of various essential oils in the local lymph node assay. Food Chem. Toxicol.; 44(5):739-46.

Lee, K.W., H. Everts and A.C. Beynen (2004). Essential oils in broiler nutrition. Int. J. Poult. Sci., 3(12):738e52.

Lu, Y., B. Gao, P. Chen, D. Charles and L.L. Yu (2014). Characterisation of organic and conventional sweet basil leaves using chromatographic and flow-injection mass spectrometric (FIMS) fingerprints combined with principal component analysis. Food Chem. Jul 1; 154:262-8.

Matsui, T., J. Tao, F. del Monte, K.H. Lee, L. Li, M. Picard, T.L. Force, T.F. Franke, R.J. Hajjar and A. Rosenzweig (2001). Akt activation preserves cardiac function and prevents injury after transient cardiac ischemia in vivo. Circulation. Jul 17; 104(3):330-5.

Mohiti-Asli, M. and M. Ghanaatparast-Rashti (2015). Dietary oregano essential oil alleviates experimentally induced coccidiosis in broilers. Prev Vet Med., 15; 120(2): 195-202.

N.R.C. (1994). National Research Council. Nutrient Requirements of Rabbits, National Academy of Science, Washington, D.C.

Nayak, I.N., R. Chinta and R. Jetti (2017). Anti-Atherosclerotic Potential of Aqueous Extract of Cinnamomum Zeylanicum Bark against Glucocorticoid Induced Atherosclerosis in Wistar Rats. J Clin Diagn Res. May; 11(5):FC19-FC23. 


\section{Ibrahim et al.}

Ozbek, H., S. Ugras, H. Dulger, I. Bayram, I. Tuncer, G. Oztruk and A. Oztruk (2003). Hepatoprotective effect of Foeniculum vulgare essential oil. Fitoterapia.; 74(3):317-319.

Pandey, A.K., A.K. Mishra and A. Mishra (2012). Antifungal and antioxidative potential of oil and extracts derived from leaves of Indian spice plant Cinnamomum tamala. Cell Mol. Biol., (Noisy-legrand).; 58(1):142-147.

Rodrigues, L.B., A.O.B.P.B. Martins, J. Ribeiro-Filho, F.R.A.S. Cesário, F.F. Castro et al. (2017). Antiinflammatory activity of the essential oil obtained from Ocimum basilicum complexed with $\beta$ cyclodextrin ( $\beta$-CD) in mice. Food Chem Toxicol. 2017 Nov;109 (Pt 2):836-846.

Saha, S., M.K. Mukhopadhyay, P.D. Ghosh and D. Nath (2012). Effect of Methanolic Leaf Extract of Ocimum basilicum L. on Benzene-Induced Hematotoxicity in Mice. Evid Based Complement Alternat Med. 2012:176385.

Schulz, H., B. Schrader, R. Quilitzsch, S. Pffefer and H. Kruger (2003). Rapid classification of basil chemotypes by various vibrational spectroscopy methods. J. Agric. Food Chem., 23; 51(9):2475-2481.

Shahverdi, A.. R.H. Monsef-Esfahani,. R, Tavasoli, a. Zaheri and R. Miriani (2007). Transcinnamaldehyde from Cinnamomum zeylanicum bark essential oil reduces the clindamycinresistance of Clostridium difficile in vitro. J Food Sci.; 72(1) S055-8.

Sharma, U.K., A.K. Sharma and A.K Pandev (2016). Medicinal attributes of major phenylpropanoids present in cinnamon. BMC Complement Altern Med., 31; 16:156.

SPSS (1997). Statistical package for Social Sciences, Chicago, U.S.A.

Tabak, M., R. Armon andI. Neeman (1999). Cinnamon extracts' inhibitory effect on Helicobacter pylori. J Ethnopharmacol. Nov 30;67(3):269-77.

Tognolini, M., V. Ballabeni, S. Bertoni, R. Bruni, M. Impicciatore and E. Barocelli (2007). Protective effect of Foeniculum vulgare essential oil and anethole in an experimental model of thrombosis. Pharmacol Res. Sep;56(3):254-60.

Visek, W.J. (1978). Diet and cell growth modulation by ammonia. Am J Clin Nutr. Oct; 31(10 Suppl):S216-S220.

Yan, L., Q.W. Meng and I.H. Kim (2012). Effect of an herb extract mixture on growth performance, nutrient digestibility, blood characteristic, and fecal microbial shedding in weaning pigs. Livest Sci. 145:189-195.

Yeomans, D.C., V. Pirec and H.K. Proudfit (1996). Nociceptive responses to high and low rates of noxious cutaneous heating are mediated by different nociceptors in the rat: behavioral evidence. Pain.; 68(1):133-40. 
تاثير بعض الأعثاب كإضافات غذائية على الأداء الإنتاجى و معاملات الهضم و بعض صفات الأبيحة وقياسات الام لبذارى التسمين

شوقى أحمد محما ابراهيم ، ماجدة مصطقى عبد الفتاح² ، جمال منصور الملاح' و هويده محمد حسن الألاوى1

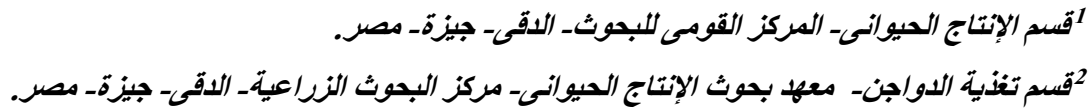

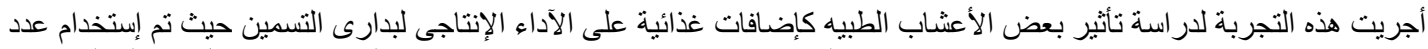

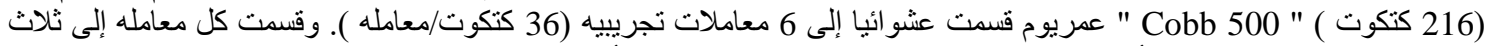

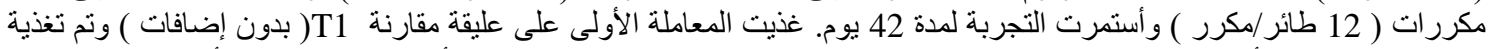

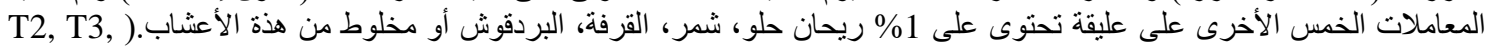
(T4, T5, T6

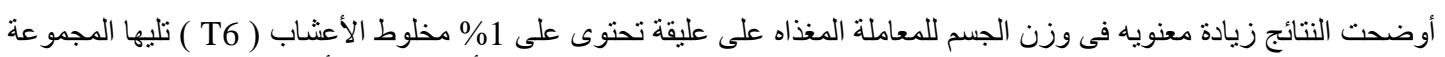

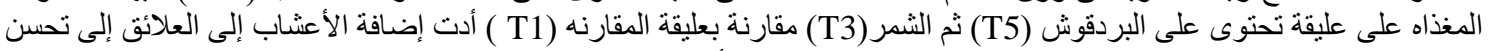

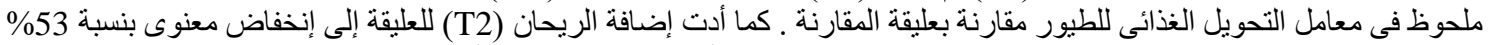

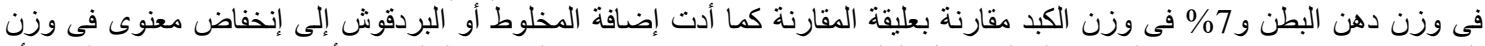

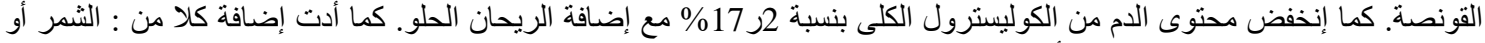

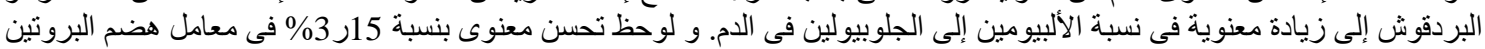
بإضافة القرفة مقارنه بعليقة المقارنة.

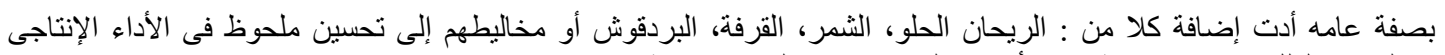

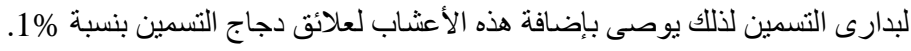

